\title{
EVALUATION OF THE TRANSIENT ELECTROMAGNETIC GEOPHYSICAL METHOD FOR STRATIGRAPHIC MAPPING AND HYDROGEOLOGICAL DELINEATION IN CAMPOS BASIN, BRAZIL
}

\author{
Antonio Abel González Carrasquilla ${ }^{1}$ and Emin Ulugergerli \\ Recebido em 21 junho, 2006 / Aceito em 14 setembro, 2006 \\ Received on June 21, 2006 / Accepted on September 14, 2006
}

\begin{abstract}
The applicability of the Transient Electromagnetic (TEM) geophysical method for stratigraphic mapping and hydrogeological delineation has been tested in terrestrial part of the Campos Basin in Brazil. The study area is located within the fluvial plain of Paraíba do Sul River, at the W edge of the continental portion of the Basin, geologically consisting of Tertiary and Quaternary sediments and a gneissic basement. Around 32 central loop TEM soundings were made with 10 or $20 \mathrm{~m}$-sided transmitter loops, to map the conductive and/or resistive zones in the subsurface, which were correlated with lithology from a drilled borehole in the test area, whose location was indicated by the present study. In general, the one-dimensional (1D) models constructed for the TEM field data suggest a 3-layer resistivity structure characterized by a resistor-conductor-resistor pattern. The shallow section of 100-500 ohm.m and $50 \mathrm{~m}$ average thickness is interpreted as correlating with clay and shaly sand formations. The intermediate layer, with thickness around $20 \mathrm{~m}$ and resistivity less than $10 \mathrm{ohm} . \mathrm{m}$, corresponds to clay. The basal resistor of 10-100 ohm.m at depths of more than $60 \mathrm{~m}$ at most sites is interpreted as the combined signature of the basal conglomerates, shaly sands and crystalline basement. Comparison with borehole data shows that the zone corresponding to the conductive geoelectrical units contains many thin layers of clay and sand that cannot be individually resolved by the TEM data and that there are no thick aquifers in the investigated area. In addition to that the shaly sand sediments have iron rich clays, which pollute groundwater, deeper resistive layers formed by conglomerates are considered the main aquifers of this area.
\end{abstract}

Keywords: transient electromagnetic, inverse one-dimensional interpretation, Campos Basin, stratigraphic mapping, hydrogeological delineation.

RESUMO. A aplicabilidade do método geofísico Transiente Eletromagnético (TEM) foi testada na parte terrestre da Bacia de Campos, Sudeste do Brasil, no mapeamento estratigráfico e no delineamento hidrogeológico. A área do estudo, situada na borda W da porção continental da bacia e dentro da planície fluvial do Rio Paraíba do Sul, consiste geologicamente de sedimentos Terciários e Quaternários sobre um embasamento gnáissico. Os trabalhos de campos consistiram de 32 sondagens com o arranjo loop central, com uma extensão lateral 10 ou $20 \mathrm{~m}$. 0 objetivo central do levantamento foi 0 de mapear as zonas condutoras e/ou resistivas em subsuperfície, as quais foram correlacionadas com a litologia de um poço perfurado na área estudada, cuja localização foi indicada a partir deste estudo. Em geral, os modelos unidimensionais (1D) resultantes da interpretação dos dados de campo sugerem uma estrutura de três camadas, a qual é caracterizada por uma intercalação resistorcondutor-resistor. A seção rasa, de 100-500 $\Omega$ m de resistividade e uma espessura média de 50 m, é interpretada como estando constituída por formações areno-argilosas. A camada intermediária, com espessura em torno de $20 \mathrm{~m}$ e resistividade menor que $10 \Omega \mathrm{m}$, corresponde à argila. 0 resistor basal, de 10-100 $\Omega \mathrm{m}$ de resistividade e em profundidades maiores que $60 \mathrm{~m}$, é interpretado, na maioria dos locais de medição, como uma combinação de conglomerados, formações areno-argilosas e embasamento cristalino. Por outro lado, a comparação com dados do poço mostra que a camada condutora intermediária contém muitas camadas finas de argila e de areia, as quais não podem ser resolvidas individualmente pelos dados experimentais. Além disso, como não existe um aqǘfero expressivo na área investigada e os sedimentos areno-argilosos são ricos do ferro, o que causa poluição na água subterrânea, isto torna a camada conglomerática resistiva profunda como o principal aqǘfero desta área.

Palavras-chave: transiente eletromagnético, interpretação unidimensional inversa, Bacia de Campos, mapeamento estratigráfico, delineamento hidrogeológico.

\footnotetext{
${ }^{1}$ Laboratório de Engenharia e Exploração de Petróleo, Universidade Estadual do Norte Fluminense Darcy Ribeiro (LENEP/UENF), Rodovia Amaral Peixoto, Km 163, Av. Brennand s/n, 29925-310 Imboacica, Macaé, RJ, Brasil. Tel. +55 (22) 2796-9700 - E-mail: abel@lenep.uenf.br

${ }^{2}$ Geophysical Department, Ankara University, Muh. Fak, Besevler, Ankara, 06100, Turkey; formerly in Observatório Nacional (ON/MCT), R. Gal. José Cristino, 77 , 20921-400 São Cristóvão, Rio de Janeiro, RJ, Brasil. Tel. +55 (21) 3878-9100 - E-mail: E.Ugur.Ulugergerli@eng.ankara.edu.tr
} 


\section{INTRODUCTION}

The surveyed area is located in Campos City, Northern of Rio de Janeiro State - Brazil, and it belongs to the terrestrial part of Campos Basin, which has a total sedimentary portion of $30.000 \mathrm{~km}^{2}$, with only $600 \mathrm{~km}^{2}$ in the continental portion (Figure 1). This basin is limited offshore by the Vitória Arc (N), Cabo Frio Arc (S) and by the ocean crust within the continental platform (E), while, on-shore, (W) it is bordered by a crystalline gneissic basement (DRM/PETROBRAS, 1997). In this terrestrial part, along of the $W$ edge of the basin, São Tomé Member grades for a thin red continental alluvium section of Quaternary age in contact with the Tertiary sediments of the Barreiras Group, overlying Mesozoic volcanic and Precambrian crystalline rocks (Figure 2). The sediments are deriving of gradation in the deposits of the deltaic system of the Paraíba do Sul river (Figure 1), in which, are possible to identify an intense integration of alluvium facies, swamp and lagoon sediments, lagoon evaporites and extensive beach lines, forming a geomorphology of coastal plain. On the other hand, the Barreiras Group, very common in the Brazilian coast, is constituted by fine argillaceous sands, gross siltstones, and conglomerates intercalate with argillaceous and bauxites layers (Figueiredo, 1985).

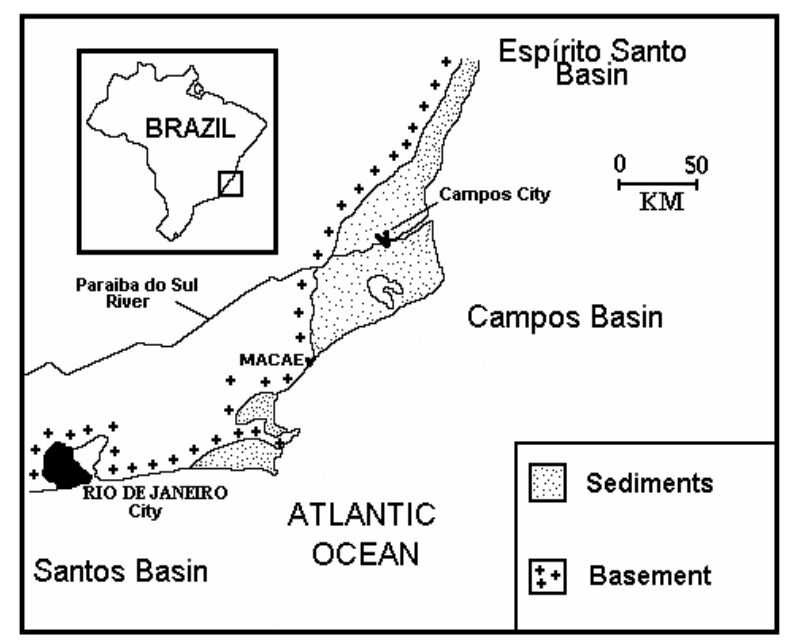

Figure 1 - Location of survey area (modified from Carrasquilla et al., 1999).

Geophysical methods in Campos Basin were firstly used by PETROBRAS (Brazilian Oil Company), which performed terrestrial and marine gravity and seismic surveys. A year later, it was drilled the first well in São Tomé Cape in 1959 (2-CST-1-RJ, Figure 2), which was perforated to obtain stratigraphic information, which did not reveal any presence of oil or gas, and, in this form, provoked the end of land prospecting works (Munis, 1993). This borehole is located around of $25 \mathrm{~km}$ SE of the studied area (see small map in Figure 2) and it showed a succession of 1.960 m of Quaternary sediments (clay, sand, sandy-clay, clayey-sand and shale) above $620 \mathrm{~m}$ of basalt flow, and then, a gneissic basement (Schaller, 1973). The Brazilian Geological Survey (CPRM), on the other hand, performed regional magnetic and gamma-spectometric surveys in Rio de Janeiro State, including Campos Basin (Mourão, 1995). With the maps derived from this study, it was possible describe the main geological trends that domain the region, which can be used as a guide in the detailed studies, as the objective of this paper. Furthermore, Fernandes et al. (1997) and Pavie (2004) performed several geophysical profiles, starting from three different cities at the coast (São Tomé Cape, São João da Barra e Barra do Furado) until crossing Campos City, using magnetotelIurics (MT) and Long Off-Set Transient Electromagnetic (LOTEM) methods (Figures 1 and 2). These works were able to show the thickness of the sediments from the surface to the basement, besides a regional geological structure in a rift form with a SW-NE direction, which is coincident with the main structural outlines of the continental part of Campos Basin.

Transient Electromagnetic Method (TEM) has been successfully applied to delineate stratified structures of geological interest, as well as, in the prospecting of groundwater, geothermal bodies, sulfide ores, deep graphite conductors, etc. (Fitterman \& Stewart, 1986), but had not been tested in Northern of Rio de Janeiro. Recently, this method has become into the most efficient technique to correct the static shift, which distorts the magnetotelluric soundings (Meju et al., 1993). In this work, we tested this geophysical technique in the specific geological conditions of onshore Campos Basin, with the objective to map the stratigraphy of a small part of the basin, and, consequently, to delineate its hydrogeologic characteristics. Thus, to supply water for the local needs, we looked for the thickness of the polluted layers and with the aim to take some precautions in the design and completion of the well, so that casing may be placed in order to prevent the natural contamination caused by mixing iron rich water coming from thin iron rich clays with potable water coming from deeper aquifer (conglomerate bands or fracture basement). This natural contamination is revealed an existing shallow well in the neighborhood of the surveyed area (30 $\mathrm{mE}$ of distance), which shows a water level around $5 \mathrm{~m}$ and produces polluted water (Carrasquilla et al., 1999).

To perform the survey using TEM method, one strong direct current is passed through a non grounded loop (Nabighian \& Macnae, 1988). At time $t=0$, this current is interrupted and a different receiving loop measures the secondary fields produced by geological heterogeneities in the subsurface that appear in the absence of inductive primary field and in the form of a decline voltage (Figure 3). In this curve, the electrical potential is mea- 


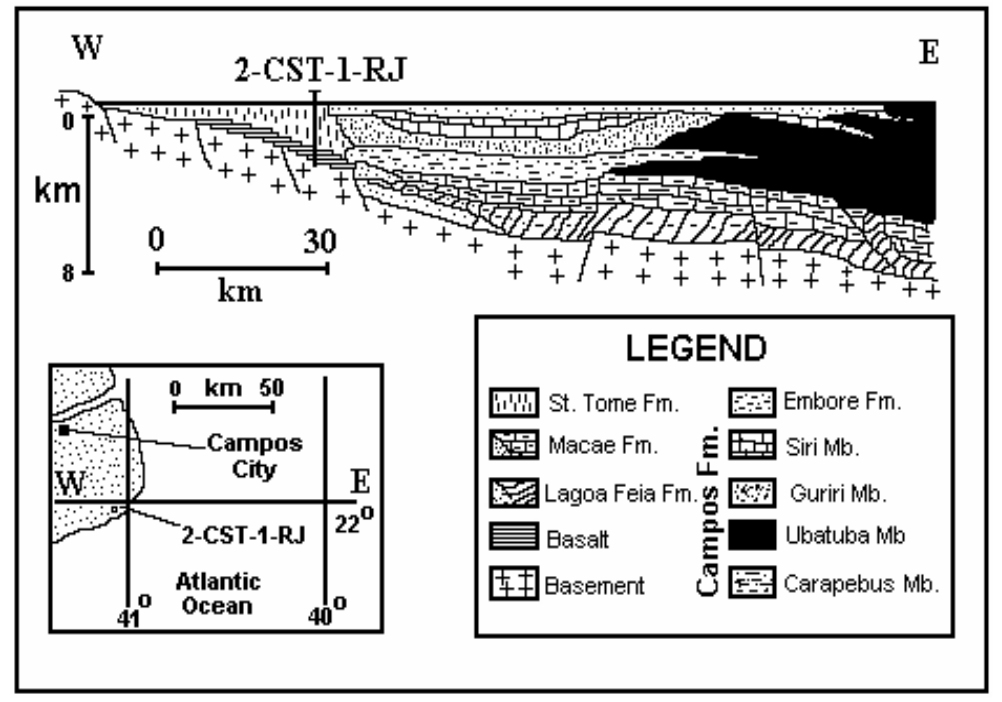

Figure 2 - Sedimentary package in Campos Basin (after Schaller, 1973).

sured in different times, which are related to different geological materials in the subsurface (Figure 4). Field procedure consists in performing several electromagnetic sounding along a profile, to show resistivity changes in distance and depth. Generally, the results can also be shown as soundings and its inverse one dimensional (1D) interpretation (Figure 10), but, usually, they are presented in apparent resistivity pseudosection forms (Figures 8 and 9).

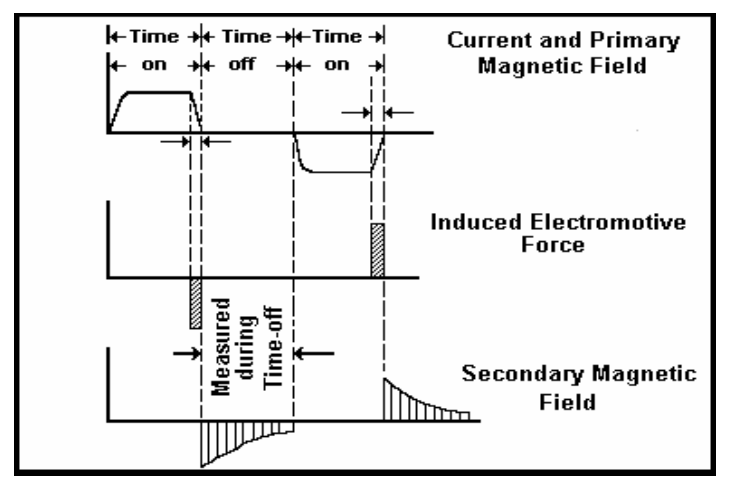

Figure 3 - Current and primary magnetic field, induced electromotive force and secondary magnetic field in TEM method (modified from Nabighian \& MacNae, 1988).
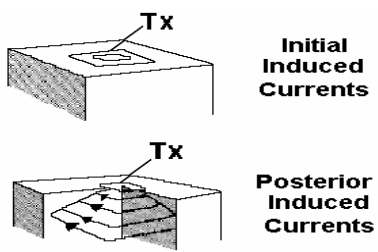

Figure 4 - Subsurface induced current system (modified from Nabighian \& MacNae, 1988)
In this survey, the used equipment measures the decay rate of the induction vertical magnetic component in $\mathrm{nV} / \mathrm{A} \mathrm{m}^{2}$, and, after that in the way of a decay voltage, these measured values are transformed in apparent resistivity ( $\rho_{a}$ in $\Omega \mathrm{m}$ ), as is shown by the following equation (Fitterman \& Stewart, 1986):

$$
\rho_{a}=\left[\frac{\mu}{4 \pi t}\right]\left[\frac{b^{2} A^{2} I}{5 t V}\right]^{2 / 3},
$$

where $\mu$ is the magnetic permeability $\left(1,2566 \times 10^{-6} \mathrm{~m} \mathrm{~kg}\right.$ $\mathrm{C}^{-2}$ ), $b$ is the square transmitter loop side (in $\mathrm{m}$ ), $A$ is the effective area of the receiver loop (area $\times$ number of coils), $I$ is the electrical current in the transmitter loop (Amp), $V$ is the transient voltage (Volt) and $t$, the time since the beginning of the transient (in Sec).

For data processing, we used the TEMIXXL commercial program (INTERPEX, 1996), while for data interpretation we utilized a $1 D$ algorithm, which utilized the dumped least square inversion algorithm (ridge regression) for horizontal layers, also incorporated in TEMIXXL. In this algorithm the vector of parameters $(\vec{P}$, $1 \mathrm{D}$ model of resistivities and thicknesses for each layer) and field observations ( $\bar{G}$, apparent resistivities) may be wrote as an approximate linear expression relating changes in $\Delta \vec{P}$ to changes in $\Delta \bar{G}$ :

$$
\Delta \bar{G}=\bar{A} \Delta \vec{P}+\varepsilon,
$$

where $\varepsilon$ is the fitting error, and $\bar{A}$ is the matrix sensitivity matrix, which it is defined as:

$$
A_{i j}=\left.\frac{\partial G_{i}}{\partial P_{j}}\right|_{P_{\sigma}},
$$


where $i$ is the number of observations and $j$ is the number of parameters.

If $\bar{A}$ is overdetermined, the departures from linearity $\varepsilon$ is small and the initial guess $P_{o}$ is close to the best-fitting vector of parameters $\vec{P}$, we may obtain $\Delta \vec{P}=\vec{P}-\vec{P}_{o}$ very simply from the algorithm:

$$
\Delta \vec{P}=\left(\bar{A}^{T} \bar{A}\right)^{-1} \bar{A}^{T} \Delta \bar{G},
$$

where the superscripts $T$ and -1 denote transpose and inverse, respectively. Equation (4), which is known as least squares method, is obtained merely multiplied both sides of Equation (2) by the generalized inverse operator:

$$
\bar{H}=\left(\bar{A}^{T} \bar{A}\right)^{-1} \bar{A}^{T} .
$$

Although Equation (4) is exceedingly fast when it converges, it is unfortunately highly unstable and usually diverges unless the data error is small and the initial guess is very accurate. In order to ensure convergence from poor initial guesses, we generally sacrifice some speed and modify Equation (4) as follows:

$$
\Delta \vec{P}=\left(\bar{A}^{T} \bar{A}+k \bar{I}\right)^{-1} \bar{A}^{T} \Delta \bar{G},
$$

where $I$ is the identity matrix and $k$ is some positive quantity. If $k$ is very large, Equation (6) approaches the gradient method, which is slow but always converges. At the other extreme, if $k$ is very small approaches Equation (4), which is very fast but may diverge. The technique of altering the value of $k$ during the process of inversion in order to ensure stable and fast convergence is known as dumped least squares or ridge regression (Rijo et al., 1977). An example of this kind of $1 \mathrm{D}$ inverse interpretation using this procedure is shown in Figure 10, corresponding to Sounding 2.

\section{FIELD EXPERIMENTS}

Measurements were made using the SIROTEM MK3 equipment, covering an area of $15.000 \mathrm{~m}^{2}$, approximately, performing 32 TEM soundings, which were obtained using a central loop array with 10 and $20 \mathrm{~m}$ of loop side, depending on geometrical constraints at the site. The survey was developed in a whole day work through two cross-profiles: one in the E-W direction (10 soundings, called Profile 1) and the other in the $\mathrm{N}-\mathrm{S}$ direction (22 soundings, called Profile 2), where the center of each square corresponds to the center of the sounding.

\section{RESULTS}

The obtained data was plotted in the form of resistivity contour maps shown in Figures 5, 6 and 7. The Figure 5 shows the resistivity values obtained in earlier times (shallower depths). It is possible to observe high resistivity values in all area, and specially, higher values in the W, NE and SE sectors. In the Figure 6, regarding middle time (intermediate depths), we can see low values of resistivity, probably associated to the presence of conductive clays at this depth. In the Figure 7, related with later times (larger depths), we can observe intermediate resistivity values on $W$ and SE of the prospected area, probably related with clay sediments mixture with sand, conglomerate or fractured basement.

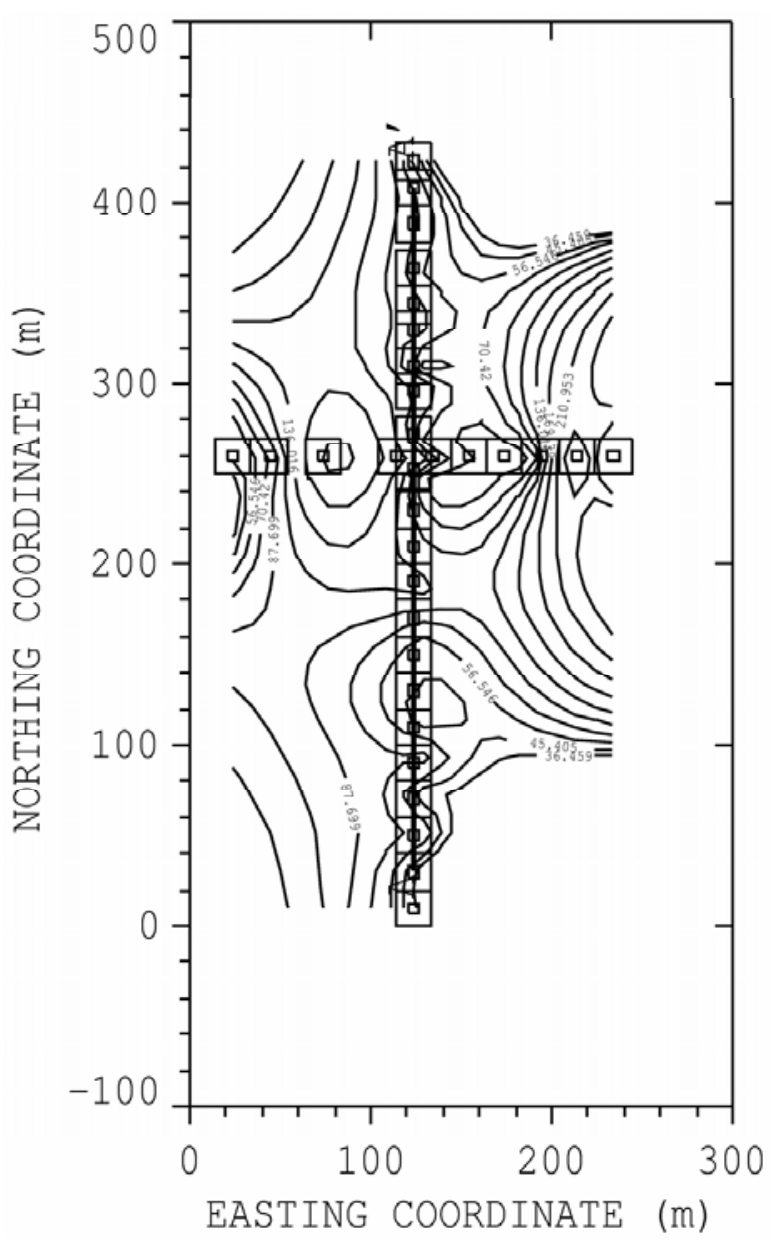

Figure $\mathbf{5}$ - Resistivity contour maps at early times.

Figures 8 and 9 show the resistivity pseudo sections for the Profiles $1(\mathrm{E}-\mathrm{W})$ and $2(\mathrm{~N}-\mathrm{S})$, respectively. It is important to realize that, in both the cases, the first strata of the pseudo sections are not shown, because, in the data processing, aiming the elimination of the high cultural noise in the area, many times were cutting when the filter was applied. For the Profile 1 (Figure 8), 


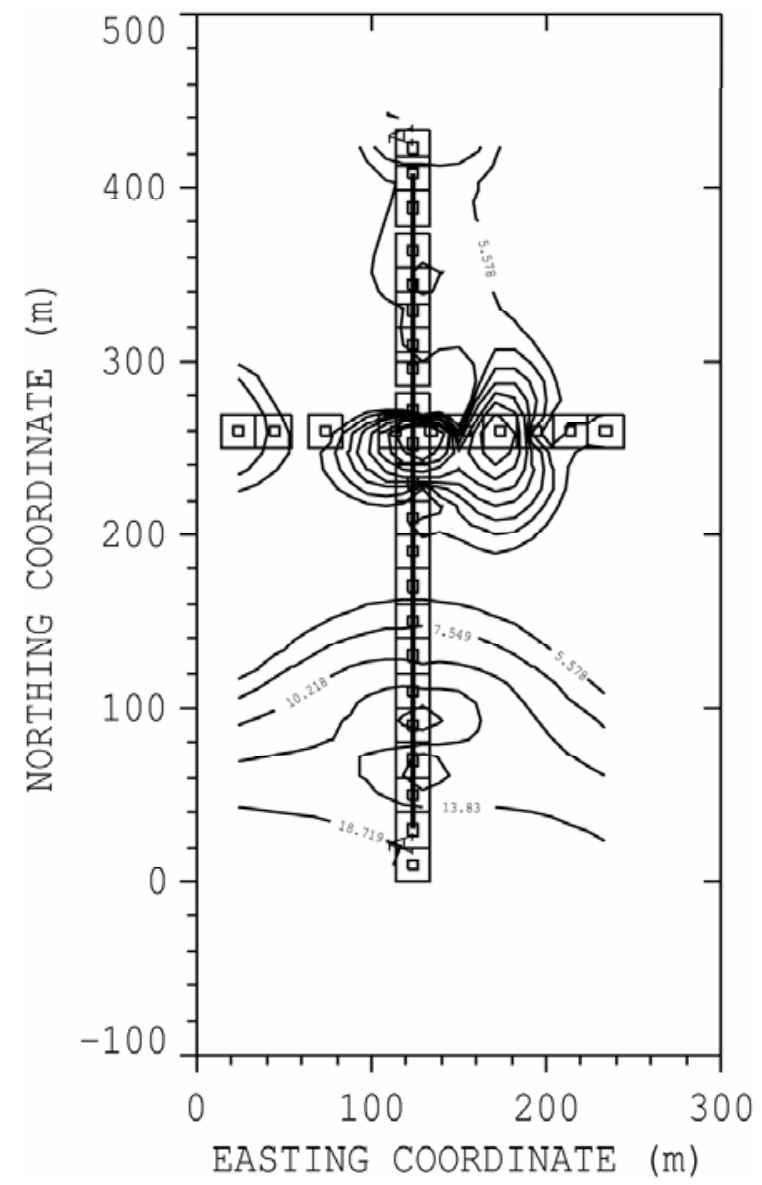

Figure $\mathbf{6}$ - Resistivity contour maps at middle times.

we can observe a first layer with high resistivity values (up to $250 \Omega \mathrm{m}$ ) and an average thickness of $30 \mathrm{~m}$. The second layer is a conductive one, with resistivity around $10 \Omega \mathrm{m}$ and thickness of $30 \mathrm{~m}$. Below these two layers, it is possible to observe alternated conductive $(10 \Omega \mathrm{m})$ and resistive $(50 \Omega \mathrm{m})$ vertical bands. Initially, it was interpreted the resistive bands as fresh crystalline rock, the conductive ones as fractures within the basement, filled by groundwater and/or clay. After the drilling, we discovered that in these depths are locating a mixture of sand and conglomerate layers with gneissic basement. Profile 2, on the other hand, shows the same resistive layer in the first meters of depth, with resitivities up to $60 \Omega \mathrm{m}$ and $30 \mathrm{~m}$ of thickness (Figure 9). Below this layer, it is possible to observe some conductive intervals with $10 \Omega \mathrm{m}$ of resistivity, but not in a continuous and clear pattern. Below $60 \mathrm{~m}$ of depth, it is observed alternative resistive and conductive bands, also interpreted initially as fresh rock and fractures. The white band that appears at a distance of $150 \mathrm{~m}$ and at $70 \mathrm{~m}$ of

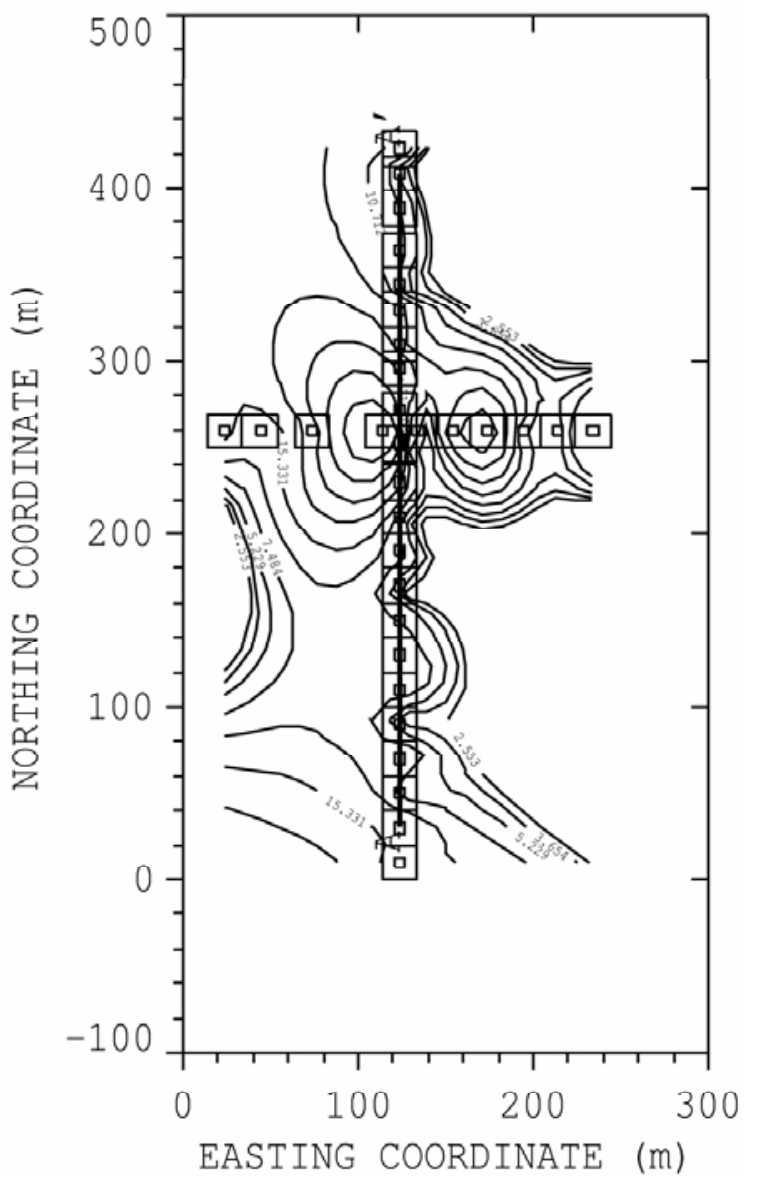

Figure 7 - Resistivity contour maps at late times.

depth, it may be caused by the absence of signal in these depths. The difference between two sections (Figures 8 and 9) could be explained by a resistivity anisotropy.

According to the results and the interpreted data, it was decided to drill a borehole in the coordinate $X=20 \mathrm{~m}$ and $Y=260 \mathrm{~m}$ in Profile 1 (Figure 5), with the initial objective reach fractures in the basement, as indicated the pseudosection of Figure 8. In Figure 10 we can observe the nearer TEM sounding interpretation (Sounding 2), for normalized voltage (above) and apparent resistivity (below) at the same times. Diverse models were tested trying to fit this data, some of them with several layers, but, the best data adjust was the model with four layers showed in Figure 10, which presented $6 \%$ of fitting error. Meantime, in Figure 11 is shown the geological material collected from the hole, which revealed the lithological profile shown (left), besides the 1D interpretation of TEM sounding (right). As mentioned before, the main aspect that is seen in this figure is that TEM method is una- 


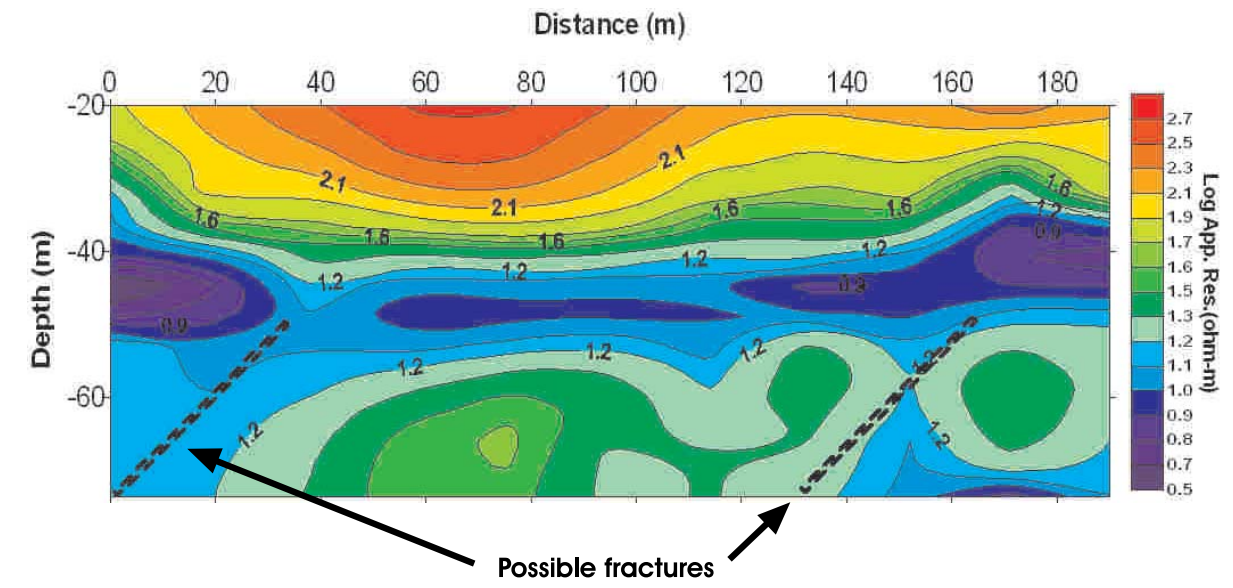

Figure 8 - Apparent resistivities pseudosection of TEM Profile 1.

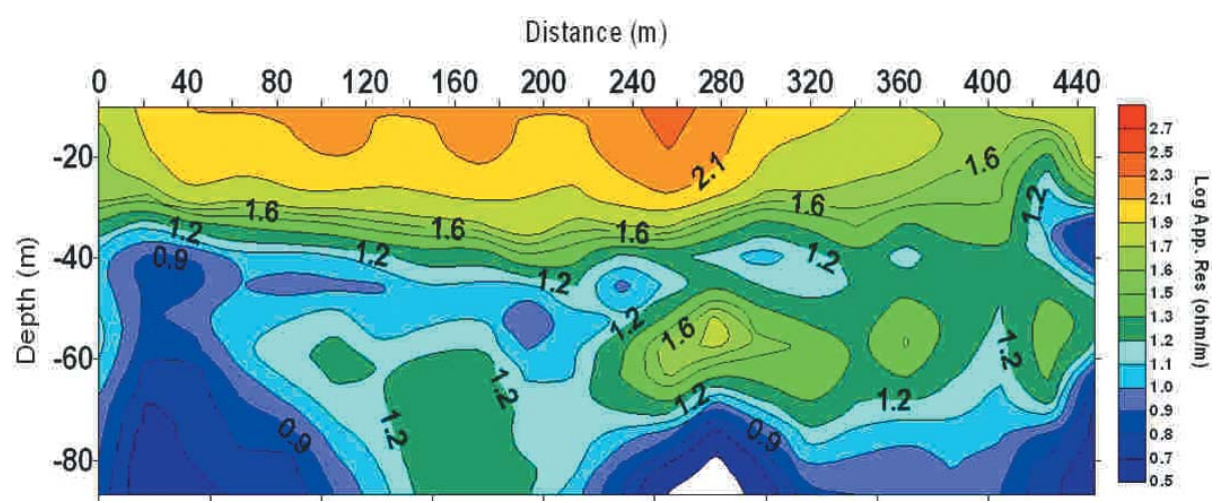

Figure $\mathbf{9}$ - Apparent resistivities pseudosection of TEM Profile 2.

ble to differentiate thin layers, especially when they are conductive and resistive in alternate way. Thus, these two intermediate layers with resistivities of $10 \Omega \mathrm{m}$ and $5 \Omega \mathrm{m}$ and thicknesses of $12 \mathrm{~m}$ and $10 \mathrm{~m}$, respectively, can be interpreted as conductivity one, associated to clay formations. On the other hand, this method registered the presence of a deep resistive geological formation that we interpreted, initially, as bedrock with fractures and fresh rock. Therefore, the drilled hole revealed that the deeper resistive geological formation as related to the presence of a combination of conglomerate and crystalline rock. Thus, among of the geophysical methods, TEM was unable to identify thin layers and to eliminate the ambiguity in the identification of deeper geological formations.

The integration of the geophysical interpretation and the geological information allowed us to decide where to set casing, in this case, along shallows layers and the iron rich clayey conductive layer (between 0 and $55 \mathrm{~m}$ ), which was suppose to pollute the groundwater, and put an appropriated screen in the deep aquifer, and thus, to permit the flux of fresh water inside the well.
The well produced a flow rate of $20.000 \mathrm{It} / \mathrm{hr}$ in the pumped test, which can be considered as reasonable. The chemical analysis of the produced groundwater in this well showed low concentrations of iron (100 ppm) but a high conductivity of $300 \mathrm{mS} / \mathrm{m}$ (related to salt concentration), which, in accord with HWO (Health World Organization) can be considered as potable water (EPA, $1990 \mathrm{a}$ and $b$ ). These results show that using integrated geophysical and geological information from wells are much better than any criteria for stratigraphic mapping and hydrogeological delineation, as can be compared with the bad neighbor boreholes drilled in this area, which produces iron rich polluted groundwater.

\section{CONCLUSIONS}

The results of this study show that the geophysical survey through TEM was capable to detect the presence of more conductive geological formations, related to the presence of clay, the average conductive layers (shaly-sand) and a deep resistive layer. Me- 

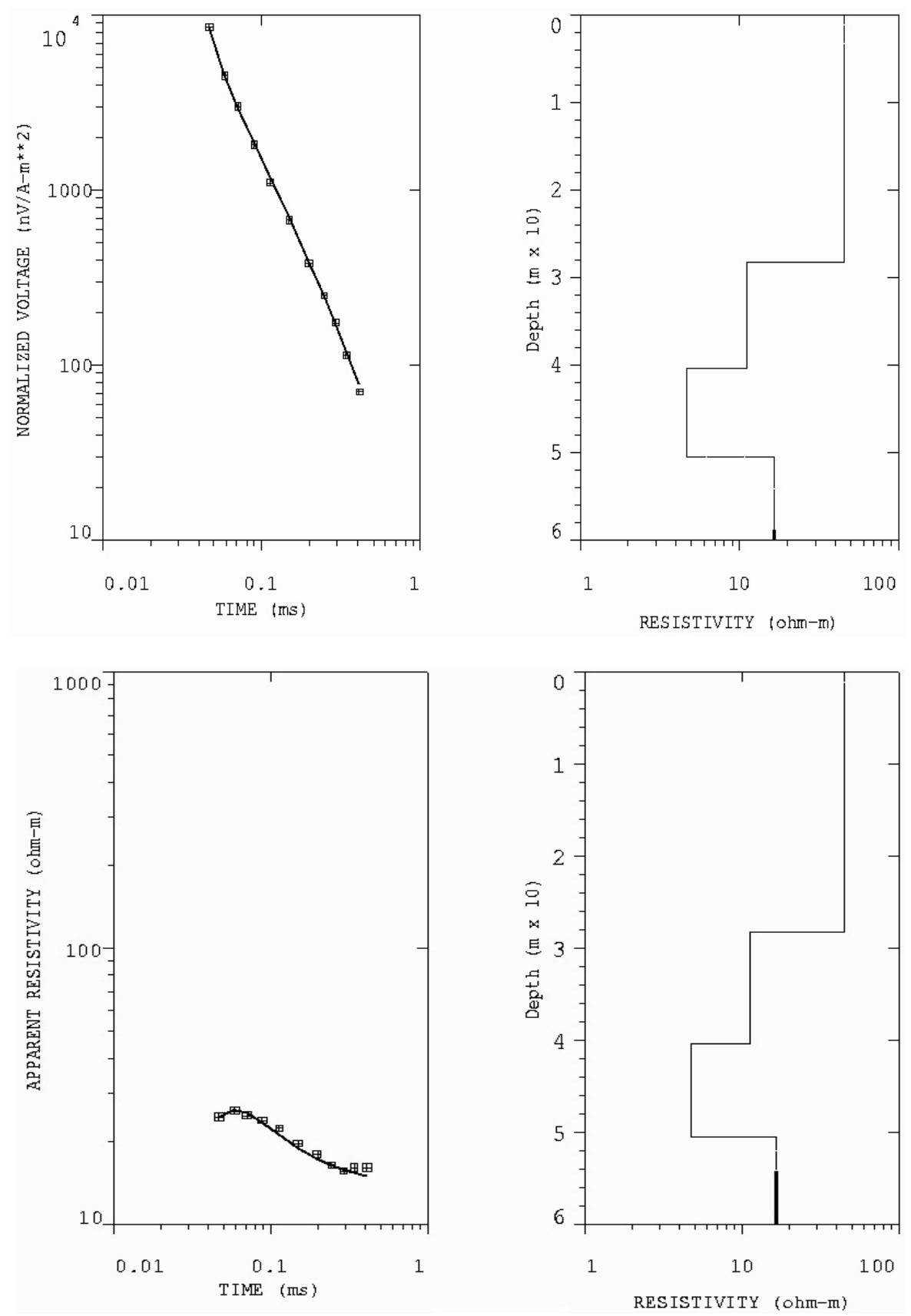

Figure 10 - TEM Sounding 2 and its inverse 1D interpretation.

anwhile, the well drilled in the area, as suggested by the results of this study, revealed that the deep resistive layer was related to a conglomerate with lens of clay, that we previously interpreted as bedrock fractures. In spite of this ambiguity, the study was important to separate conductive and resistive layers, and, by the history of the area, freshwater can be only found in resistive layers related to porous sediments (sand or conglomerate) or in fractu- res present in the bedrock. Finally, after the drilling of wells in this area, it is advisable to perform well logging profiles, in order to make a better differentiation between sandy and shaly geological formations, showing porosities, permeabilities and temperatures of each layer, which are important information to indicate the water table, and how should be set casing in order to avoid contaminated water. 


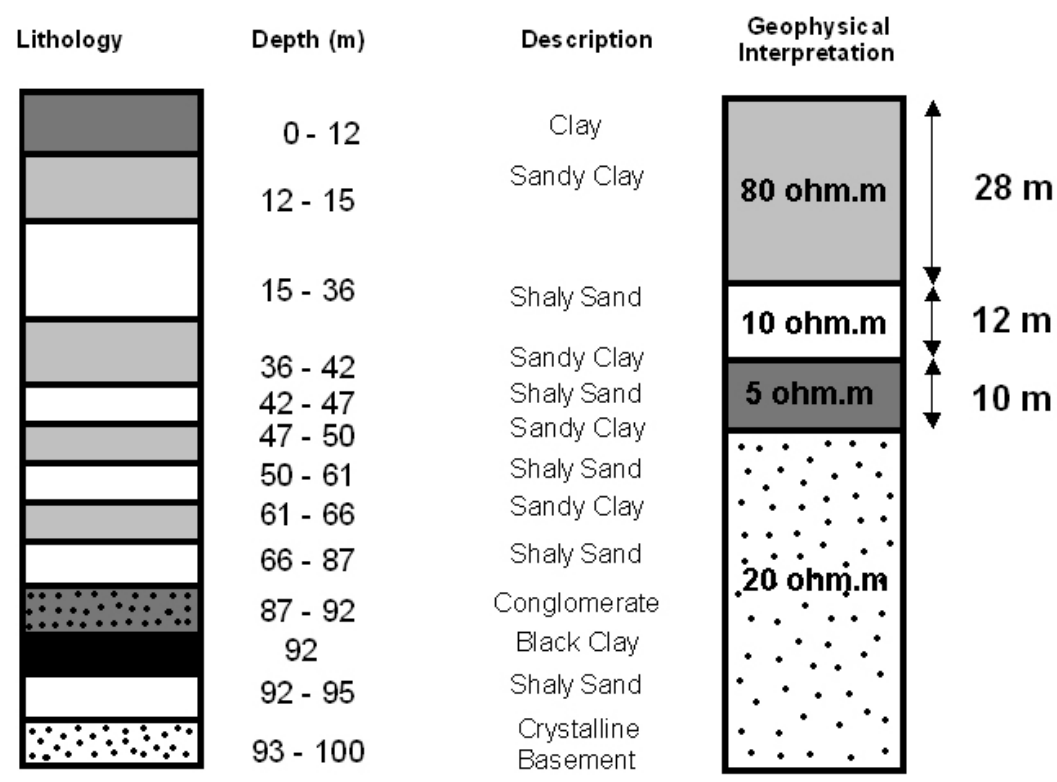

Figure 11 - Well drilled besides TEM Sounding 2 and its inverse 1D interpretation.

\section{ACKNOWLEDGEMENTS}

This work was supported by grants from Brazilian Program to Support and Develop of Science and Technology (PADCT III) and Rio de Janeiro State Science Foundation (FAPERJ). We also acknowledge the Brazilian Research National Council (CNPq) for providing research fellowship. One of the authors (E.U.) thanks University of Ankara (Turkey) for providing support as a visiting researcher in ON/MCT. Finally, we thank Dr. Maxwell Meju from Lancaster University - UK for the revision of the text.

\section{REFERENCES}

CARRASQUILLA A, FONTES SL, LA TERRA EF \& GERMANO CR. 1999 Estudo geofísico preliminar com os métodos TEM/FEM na Planície Costeira Norte Fluminense. Proceedings, $6^{\text {th }}$ International Congress of the Brazilian Geophysical Society, Rio de Janeiro, CD-ROM SBGf26.

DRM/PETROBRAS. 1997. Mapa Geológico do Estado do Rio de Janeiro. Escala 1:400000.

EPA. 1990a. Ground Water. Volume I: Ground Water and Contamination. US Environmental Protection Agency, Office of Research and Development, Center for Environmental Research Information, Cincinnati, 144 p.

EPA. 1990b. Ground Water. Volume II: Methodology. US Environmental Protection Agency, Office of Research and Development, Center for Environmental Research Information, Cincinnati, 141 p.

FERNANDES M, CARRASQUILLA A, FONTES S \& RIBEIRO HJS. 1997. Primeiros resultados com o método geofísico magnetotelúrico no es- tudo das feições geológico estruturais da porção continental da Bacia de Campos. Proceedings, V Simpósio de Geologia do Sudeste, Penedo RJ, p. 365-367.

FIGUEIRED0 AMF. 1985. Geologia das bacias brasileiras. In: VIR0 EJ (Ed.). Avaliação de formações no Brasil. Schlumberger, Rio de Janeiro, I: $1-38$.

FITTERMAN DV \& STEWART MT. 1986. Transient electromagnetic sounding for groundwater. Geophysics, 51(4): 995-1005.

INTERPEX Ltd. 1996. Software Operation Manual TEMIXXL. Vol. I e II.

MEJU MA, FONTES SL \& OLIVEIRA MFB. 1993. Joint TEM/AMT feasibility studies in Parnaíba basin, Brazil: Geoelectrostratigraphy and groundwater resource evaluation in Piauí state. In: International Congress of the Brazilian Geophysical Society. Expanded Abstracts, Rio de Janeiro, SBGf, 3: 1373-8.

MOURÃO LMF. 1995. Base de Dados de Projetos Aerogeofísicos do Brasil (aero). Proceedings, $4^{\text {th }}$ International Congress of the Brazilian Geophysical Society, Rio de Janeiro, 237-239.

MUNIS M. 1993. Aplicabilidade do método de Euler na interpretação de dados aeromagnéticos da Bacia de Campos. Master Thesis, ON/MCT, Rio de Janeiro. 126 pp.

NABIGHIAN MN \& MACNAE JC. 1988. Time domain electromagnetic prospecting methods. In: NABIGHIAN MN (Ed.). Electromagnetic methods in applied geophysics. Vol. 2, Part A, Chapter 6, 427-520.

PAVIE G. 2004. Análise geofísica-geológica da porção emersa da Bacia de Campos através de uma metodologia integrada. Master Thesis, LENEP/CCT/UENF, Macaé - RJ, 183 pp. 
RIJO L, PELTON WH, FEITOSA EC \& WRAD SH. 1977. Interpretation of apparent resistivity data from Apodi Valley, Rio Grande do Norte, Brazil. Geophysics, 42: 811-822.
SCHALLER H. 1973. Estratigrafia da Bacia de Campos. Anais do XXVII Congresso Brasileiro de Geologia, Aracaju, 3: 247-258.

\section{NOTES ABOUT THE AUTHORS}

Antonio Abel González Carrasquilla is PhD in geophysics (Federal University of Pará, Brazil), specialist in electromagnetic methods for natural resources prospecting, mainly groundwater and oil. Actually, he is Professor and Head of the Petroleum Engineering and Exploration Laboratory of the North Fluminense State University in Macaé - RJ, Brazil.

Emin Ulugergerli is PhD in geophysics (University of Leicester, England), specialist in numerical modeling for electromagnetic methods. Actually is Professor in University of Ankara, Turkey, but spent one year as Visiting Professor in National Observatory, Ministry of Science and Technology, in Rio de Janeiro - RJ, Brazil. 